\title{
Disney is a Gendered World How a Little Mermaid Becomes a Sirenetta
}

Eleonora Federici, Emanuela Ammendola, Luisa Marino ${ }^{1}$

\begin{abstract}
Children's literature is a breeding ground for translation and adaptation; this is demonstrated by the great amount of animated movies inspired by children's books, where characters coming from literary fairy tales often reappear changed in their multimodal versions. The article aims at analysing the intersemiotic translation of Hans Christian Andersen's The Little Marmaid from literature to the screen, focusing in particular on the process of Disneyfication the literary fairy tale underwent in order to become a blockbuster. Moreover, the article draws attention to the process of dubbing dialogues and songs in the Italian La Sirenetta showing how it perpetuates sterotyping gender roles.
\end{abstract}

\section{Key Words}

Children's literature, The Little Mermaid, Adaptation, Disney, Audiovisual Translation

\section{Content}

1. Introduction

2. The Little Mermaid: An Old Story from Orality to Literature

3. The Little Mermaid Goes on Screen

4. Walt Disney's productions: how to adapt a literary source and make it a blockbuster

5. Singing the Italian Sirenetta

6. Conclusions

Bibliography

1 The essay has been thought and discussed by the three authors and written as follows: sections 1 and 2 by Luisa Marino, sections 3 and 4 by Eleonora Federici and sections 5 and 6 by Emanuela Ammendola. 
Eleonora Federici, Emanuela Ammendola, Luisa Marino | Disney is a Gendered World | DOI: 10.12977/ocula2019-15

\section{Introduction}

In 2014, the English author Neil Gaiman published The Sleeper and the Spindle, a fairy-tale adaptation that combines both the story of Snow White and Sleeping Beauty. The book, which features illustrations by Chris Riddell, is an example of «intermediality in the broad sense» (Rajewsky 2005:50) as it establishes a relationship between two codes and crosses boundaries between different media. In so doing, it unveils infinite possibilities for de-codification and recodification. With The Sleeper and the Spindle, Gaiman and Riddell (re) tell the stories of two of the most well-known classical princesses. However, by questioning the hegemonic models of sexuality and femininity, they offer an alternative narration of heteronormativity and an alternative model of personal success for women. Thus, the book is an example not only of the enduring fascination and efficacy of processes of adaptation; it is also a positive example of the relationships fairy-tale adaptations can have with the social dynamics of power and with their subversion. The Sleeper and the Spindle is just one of the latest examples of a fairy tale adapted to fit a multimodal format and what happens in the passage from one medium to the other. In the case of fairy tales, simple rewritings have proven to be common both in the translation from source text (ST) to target text (TT) and in the passage from one medium to the other, such as from literary text to audiovisual representation (cfr. Desmidt 2009). The aim of this article is to explore the transformation of the story of the Little Mermaid through time in its various reincarnations and through its translations/rewritings/adaptations from one medium to another, focusing on the specific category of gender and highlighting how in the passage from a literary text to an audiovisual one, some translation choices reinforce certain ideological values and social perceptions of gender roles. Since this kind of analysis would be vast and not feasible in just one article we will tackle briefly the transmission of the oral source and of the original text into the Italian context, we will then refer to Walt Disney's representations of the 'little mermaid' and, subsequently, we will analyse some extracts from the blockbuster movie comparing the American and the Italian versions in order to outline how gender roles are culturally and linguistically constructed. This act of adaptations and revisions can be seen also in the translation of musical texts as we will demonstrate in the last section of the article.

In our analysis we intend to demonstrate how Walt Disney's (1989) adaptation of Hans Christian Andersen's The Little Mermaid changes the representations of feminine figures not only through the creation of new characters and transformations of old ones, but also through changes in dialogues, and in the songs and musical texts used in the movie. We will underline some aspects which make the movie different from its literary hypotext, discussing the representation of gender roles in different characters. We will also focus on some examples of song translation into Italian for the Italian audience, a 
Eleonora Federici, Emanuela Ammendola, Luisa Marino | Disney is a Gendered World | DOI: 10.12977/ocula2019-15

fundamental element both in the narration of the story and in the viewers' reception. This will give us the possibility of outlining the specific linguistic and cultural implications that are involved in translation choices from one language/cultural context to another. From this perspective, both the trans-medial adaptation of the fairy tale and the translation/adaptation of the script will be regarded as mechanisms of power that enact non-neutral processes of change.

\section{The Little Mermaid: An Old Story from Orality to Literature}

Fairy tales were born from the Volk, that is from oral folk culture. They were told by skilled storytellers and originally based on myths. As folk tales, fairy tales had the power to reinforce the national, social and class bounds within a community and, since they came from everyday life experience, they mirrored the beliefs, ideas and behaviours of the community from which they originated, adapting to changes as they arose (cfr. Haase 1999). The invention of the modern printing press in the second half of the fifteenth century was a fundamental turning point in the history of fairy tales as a literary genre, as it caused a shift in both the way in which fairy tales were told and the nature of their audience. From that moment fairy tales ceased to be folk tales that passed from mouth to mouth and became tales whose written form facilitated their spread among the educated classes. The institution of the fairy tale as a literary genre occurred in France in the late seventeenth century, when French writers started to make a distinction between the contes de fées (fairy tales) and the contes populaire (popular tales). The difference between fairy tales and popular tales was that the former complied with the tastes of the aristocracy and the bourgeoisie, in regard to both content and aesthetics, and for this reason they were chosen as "literary fairy tales". Thus, what we know today as "literary fairy tales" are just a small part of the folk tales which came from the oral tradition. Orality continued to be the creative substratum of literary fairy tales, though the introduction of both the book as a new medium and the first copyright laws caused significant changes in conceptions of ownership (cfr. Haase 1999: 361). Such changes impacted the nature of fairy tales as part of the mnemonic archive of a community transmitted from generation to generation. This change became evident in cases like that of the Grimm brothers, who in their famous book (Kinder- und Hausmärchen, 1812) merely claimed to have collected pre-existing German folktales and yet whose stories have become known as the "Grimm's fairy tales". Andrew Teverson (2013) affirms that the publication of the Grimm's Kinder- und Hausmärchen sparked two different trends in the European literature and folklore of the nineteenth century. On the one hand, folklorists across Europe started to publish anthologies that brought together legends, tales and songs with the aim of preserving the heritage of their nation of origin. On the other hand, writers, poets and playwrights used the Grimm's stories as a basis for their works. In this case, the objective was not the preservation of national heritage but the employment of a well-known form of writing to express the original ideas and artistic values of the writer. Hans Christian Andersen falls into the latter camp. Between 1835 and 1872 he wrote a corpus of 156 fairy tales. Though 
Eleonora Federici, Emanuela Ammendola, Luisa Marino | Disney is a Gendered World | DOI: 10.12977/ocula2019-15

he used some techniques which were typical of oral narration, his stories are not normally defined as folk tales as they were his own invention and cannot be considered re-elaborations of an oral tradition. Hans Christian Andersen's Den lille Havfrue (The Little Mermaid) was published for the first time in Denmark in 1837 in the collection known as Eventyr, fortalte for Børn. Første Samling Tredie Hefte (Fairy Tales Told for Children). Though the author asserted that his fairy tales had no models, scholars such as Finn Hauberg Mortensen (2008) have found in some old Danish ballads, and even in the works of some of Andersen's contemporaries, themes which could have possibly inspired the author to write his stories. While the reconstruction of the genealogy of Andersen's fairy tale goes beyond the scope of this article, it is useful to remember that Den lille Havfrue has become known in English thanks to a number of translations, which in some cases were not in fact based on the Danish source text. In 2005, the scholars of the Andersen Centre of the University of Southern Denmark established a numbering system through which the complete literary production of the author could be catalogued. The register provides information about several editions in which the story of The Little Mermaid appears and lists the "standard English translation" of the fairy tale as the 1949 publication by Jean Hersholt.

In Italian the most complete and reliable edition of Andersen's fairy tales was published by Donzelli in 2001 with the title Fiabe e Storie using Bruno Berni's translations from Danish. The Italian translation (as with previous translations in other European languages) contains shortened versions of Andersen's fairy tales, often published as single illustrated tales for children rather than as part of extended selections of writings. It is important to stress that for many of these versions the ST was not the original Danish text but a text in French or German, meaning the Italian versions of Andersen's stories were often the result of a translation made from a translation. It was only thanks to Maria Pezzè Pascolato's later translations from the Danish that the Italian audience was finally able to read the first collection of Andersen's fairy tales as they had originally appeared. The collection was published in 1904 by Hoepli under the title of Quaranta novelle and was so successful that the publisher decided to publish two more extended editions of Andersen's fairy tales Nuove novelle (1938) and Nuovissime novelle (1955) with new translations by Mary Tibaldi Chiesa. In 1954, the publisher Einaudi published Fiabe di Andersen, which included around one hundred fairy tales, becoming the largest collection of Andersen's fairy tales in Italian. Only one collection previous to Donzelli's Fiabe e Storie had contained Andersen's complete works: Newton Compton's 1993-94 edition. However, this edition collected old and new translations which were often based on a German ST rather than the Danish original. Thus, the motivation behind the Donzelli edition was the necessity of collecting for the first time in a single edition the Italian translations from Danish of all of Andersen's fairy tales, offering the readership the possibility of perceiving Andersen's originality through a direct and coherent translation. The book was then re-printed by Donzelli in 2005 and 2014 (with illustrations by Fabian Negrin) and re-published by Feltrinelli in 2012 in the series "Universale Economica I Classici". 
Eleonora Federici, Emanuela Ammendola, Luisa Marino | Disney is a Gendered World | DOI: 10.12977/ocula2019-15

\section{The Little Mermaid Goes on Screen}

A literary text cannot be easily compared to the script of a movie inspired by that same text. The movie script has a hybrid and ever-changing nature; in the hands of the director it is a tool, a work in progress that can be altered at all stages of production, and for the dialogue editor it acts essentially as a map, containing information concerning the relationship between oral and visual elements. Yet, even if a literary text and a script originate from different processes of creation and are destined to different addressees, Disney's adaptation of Andersen's The Little Mermaid allows us to reflect on the ways in which the aspect of orality remains present even where a story has made the passage from the literary medium to the audiovisual one. We have focused on orality not just because it is an enduring characteristic of the fairy-tale tradition as a literary genre but because it also represents a "practice for the transmission of knowledges and the envisioning of alternative futures» (Bacchilega 2006: 72). In other words, the enduring presence of orality seems to suggest that adaptation, remediation and intersemiotic translation are all processes that concur to keep the genre of fairy tale alive and to reconstruct the same author and audience experience in all its possible variations. Drawing on Gérard Genette's conceptualization of transtextuality (cfr. Genette 1997), and in particular on his definition of hypertextuality, we argue that, in the case of Disney's The Little Mermaid, the persistence of orality contributes to a strengthening and renewing of the relationship between the literary hypotext and the audiovisual hypertext. Looking at the script of the Disney cartoon, we see the ways in which the aspect of orality contained in the literary text is preserved in the creation of «a text in the second degree» (Genette 1997: 5). Indeed, in this case, the features of orality are captured through both verbal and non-verbal signs whose function is to efficiently encode all the information actors need to interpret or dub the characters of the story.

An example from a dialogue between Triton, Sebastian and Flounder taken from The Little Mermaid script demonstrates how a semiotic analysis of this multimodal text could pave the way for an in-depth study into the relationship between orality and its visual representation in the scripts of fairy-tale adaptations for the screen:

\section{Triton:}

As a result of your careless behaviour -

\section{Sebastian:}

Careless and reckless behaviour!

Triton:

- the entire celebration was, er -

\section{Sebastian:}

Well, it was ruined! That's all. Completely destroyed! This concert was to be the pinnacle of my distinguished career. Now thanks to you I am the laughingstock of the entire kingdom!

Flounder: 


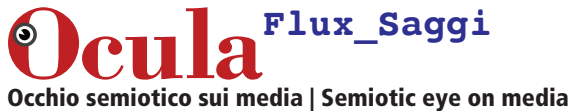

Eleonora Federici, Emanuela Ammendola, Luisa Marino | Disney is a Gendered World | DOI: 10.12977/ocula2019-15

But it wasn't her fault! Ah - well - first, ahh, this shark chased us - yeah - yeah! And we tried to - but we couldn't - and - grrrrrrrrr - and - and we - whoooaaaaaa - oh, and then we were safe. But then this seagull came, and it was this is this, and that is that, and -

Triton:

Seagull? What? Oh - you went up to the surface again, didn't you? DIDN'T YOU?

Here, the use of the dashes at the end of Triton's lines underlines the presence of overlaps, suggesting that the speaker will end the sentence in the successive turn. On the other hand, the dashes present in the body of Flounder's line stand for self-interruptions resulting from the speaker's need to rearrange sentences as they are spoken. Together with the exclamations and the onomatopoeic utterances, these elements indicate the speaker's uncertainty and hesitation. Furthermore, in the script, capital letters are used to indicate a change in the timbre of the character's voice. So, it is possible to assert that for a script, the result of intersemiotic translation is evidenced both in the layout and in the use of specific signs; visible traces of a highly informative text.

Discussing intersemiotic translation, many scholars have outlined the inevitable transformation and adaptation a text undergoes when it is transferred from one medium to another (v. Jakobson 1959; Garcia 1990; Eco 2000; Mc Farlane 2007), a process which creates a tension between "fidelity" to the original source and the necessity of adapting it for the target audience. Adaptation means transformation, a new interpretation of an artistic work from text to screen and a transposition between two semiotic systems (cfr. Dusi 2006). The suffix "trans" accentuates the positive connotation of a crossing over from one text to another, a shaping of the original text into a new form, in contrast to the "negative" connotation of the term "adaptation" which implies a superiority of the source text. Similarly, Linda Costanzo Cahir and James M. Welsh have underlined the difference between adaptation and translation, because «to adapt is to move that same entity into a new environment» (Costanzo Cahir and Welsh 2006: 14), while to translate means a passage into a new medium via «a process of survival and generation» (Costanzo Cahir and Welsh 2006: 14), so that «through the process of translation a fully new text - a materially different entity - is made one, that simultaneously has a strong relationship with its original source, yet is fully independent from it» (Costanzo Cahir and Welsh 2006: 14). Adaptation Studies have shown that «transposition to another medium, or even moving within the same one, always means change [...] and there will always be both gains and losses» (Hutcheon 2006: 16). What we are dealing with in the case of the Disney adaption is "medial transposition", i.e. «the transformation of a given media product (a text, a film, etc.) or of its substratum into another medium» (Rajewsky 2005: 51) which is "production-oriented". The result is a product that has to respond to media-specific characteristics, implying that some meaning will inevitably be lost in the process of remediation.

The translation of a literary text into a visual one implies that the original material will go through some process of de-contextualisation. As Lawrence Venuti has highlighted 
Eleonora Federici, Emanuela Ammendola, Luisa Marino | Disney is a Gendered World | DOI: 10.12977/ocula2019-15

an adaptation is likely to decontextualize these materials in a much more extensive and complex way, not only because of the change in medium, but because of the license routinely taken by filmmakers. Portions of the prior materials might be eliminated or altered because a filmmaker has chosen not to incorporate them in the film at all or in the same form, including subplots and plots twists, scenes, dialogue, characters and descriptions of settings, images from visual art, and historical figures and events. (Venuti 2007: 30)

The audiovisual form stands as a new entity and should not be analysed as a mere adaptation of the original literary text. Rather, it should be considered as a wholly new work and «treated as relatively autonomous from the materials it adapts», as Venuti states, because «its relationship to those materials consists of a simultaneous resemblance and difference, mimetic but never an identity» (Venuti 2007: 27). It is clear that in the passage between the two texts an interpretative choice is made and some elements are omitted or transposed through the use of techniques such as omission/deletion of characters, condensation or expansion of parts of the original literary text, additions to focus on specific characters or selected parts of the story, and variations, such as the adaptation of names for a different language. Ultimately, the aim of the audiovisual text is to captivate the audience; it is addressed to a new target viewer. Scholars have outlined how changes from literary to audiovisual texts can be considered as strategies for establishing an analogy with the source and the target text (cfr. Bluestone 2007), as part of a process of appropriation required to adapt to the different cultural context of the new audience (cfr. Vayone 2006).

The Little Mermaid is an animated feature length film lasting approximately 79 minutes. It came out in the US in 1989 and was released worldwide to great success, so much so that the producers then decided to create both a sequel, The Little Mermaid II: Return to the Sea in 2002, and a prequel, The Little Mermaid: Ariel's Beginning in 2008. A prequel television series was aired from 1992 to 1994, depicting Ariel's life as a mermaid under the sea with Sebastian, Flounder and her father. Ariel appears in all 31 episodes of the series, which is set in an unspecified time before the first film. A series of twelve prequel novels was also published in 1994 by Disney Press, following young Ariel's adventures living under the sea: Green-Eyed Pearl and Nefazia Visits the Palace by Suzanne Weyn; Reflections of Arsulu and The Same Old Song by Marilyn Kaye; Arista's New Boyfriend and Ariel the Spy by M. J. Carr; King Triton, Beware!, The Haunted Palace and The Boyfriend Mix-Up by Katherine Applegate; The Practical-Joke War by Stephanie St. Pierre; The Dolphins of Coral Cove by K. S. Rodriguez; and Alana's Secret Friend by Jess Christopher. The novels mostly focus on the domestic setting of Ariel and her sisters living together. In 1992 Disney Comics released a four-issue The Little Mermaid Limited Series comic book series. In 1994 Marvel Comics released its own title, Disney's The Little Mermaid, which ran for twelve issues. All these comics are prequels to the film and feature Ariel the mermaid living under the sea having adventures with Flounder and Sebastian or thwarting the attempts of villains that wish to take over Atlantica. 
Eleonora Federici, Emanuela Ammendola, Luisa Marino | Disney is a Gendered World | DOI: 10.12977/ocula2019-15

The script of the movie was written by John Musker and Ron Clements, who were also co-directors. The music, which is a central element of the adaptation, was written by Alan Menken and the lyrics by Howard Ashman. However, the Disney movie is not the first audiovisual transposition from the literary text. As early as the 1940s Walt Disney and his staff had worked on a short film of the same story. Kay Nielsen, an important illustrator for children's books painted a watercolour for the purposes of the film, which is still in the Disney archives, proof of this first attempt to recreate the Little Mermaid tale. In 1999 Jack Zipes wrote a pivotal essay about Disney fairy-tale adaptation in which he discussed the evolution of the fairy tale as a literary genre and the US production company's attitude towards the question of fairy-tale ownership. Zipes's hypothesis was that «Walt Disney cast a spell on the fairy tale» (Zipes 1999: 332), meaning that, through his films, Disney had institutionalized a process of appropriation that changed the way in which entire generations of children and adults enjoyed classical fairy tales. Disney used technological advances to offer adapted versions of classical (read "familiar") fairy tales and, in attempting to connect tradition and innovation, he in fact managed to do something revolutionary: he bypassed the issue of ownership and was able to achieve a situation where the audience could «see and read the classical tales through his lens» (Zipes 1999: 333). Similarly, Lluch Crespo suggests that Disney's product is the result of his willingness to create magical illusions and global narratives (cfr. Lluch Crespo 2002). What Disney brings to his Little Mermaid is the conscious perpetuation of traditional, patriarchal models of femininity, displayed through a captivating, cheerful adventure in technicolour lasting eighty-three minutes. Walt Disney's movie chimes perfectly with late- $20^{\text {th }}$ century US patriarchal society. Indeed, it reinforces gender bias through a personal re-interpretation of the characters of the classical fairy tale or through the introduction or elimination of elements connected to the relationship between gender roles and the dynamics of power. As gender bias is present in almost all cultures, the movie has worked well everywhere. On closer inspection, therefore, what could be perceived as the simple transposition of an "innocent" fairy tale in fact reveals conscious choices concerning the representation of gender. In other words, concealed in Disney's adaptation choices are "not-so-innocent" dynamics of power. The control that these dynamics exercise on the imagination of children needs to be detected and deconstructed, because, as Zipes points out, "fairy tales stick" (cfr. Zipes 2006); they continue to be hugely popular regardless of what form they take. Scholars have outlined both the tendency of Disney's productions to adapt to historical and cultural contexts (cfr. Ozgenalp 2004) and the willingness to leave out of the films any of the psychological or social complexity present in the literary hypotext (cfr. Darcy 2004). The Little Mermaid adaptation is selective in the elements it takes from the original story, transforming the narrative through the addition of new elements or expansion of parts of the original. The movie is an example of both "traditional translation" and "radical translation" (cfr. Costanzo Cahir 2006: 16-17) as it maintains some traits of the fairy tale while altering many others.

In Andersen's story, the Little Mermaid is the youngest and the prettiest of the six children of the Sea King. She is not allowed to swim to the sea surfa- 
Eleonora Federici, Emanuela Ammendola, Luisa Marino | Disney is a Gendered World | DOI: 10.12977/ocula2019-15

ce and the only things she knows of the "world above" are passed down from her elder sisters when they get permission to rise to the surface on their birthdays. Unlike Ariel, Andersen's unnamed Little Mermaid does not collect human objects and does not possess a statue representing a handsome boy, but she is curious about human life out of water because she considers that world exotic and is fascinated by the possibility of knowing or discovering something new. Ariel is obsessed with human beings and their artefacts and keeps a collection in a cave. Andersen's Little Mermaid has no desire to become a human being until she discovers that humans have an immortal soul. So, while Ariel is fascinated by the idea of having two legs in order to walk, dance and make Prince Eric fall in love with her - she longs for male protection - Andersen's character is much more attracted by the possibility of having a soul. Indeed, Andersen's mermaids can live up to three hundred years but after their death they become part of the sea foam. The only way for them to obtain an immortal soul is by making a man fall in love with them. Thus, while Andersen's classical story in many ways presents an image of woman which conforms with the patriarchal canons of nineteenth century society, the image the Disney's movie conveys is certainly not that of an independent young woman who aims to emancipate herself from a male-centred society. If it is true that Andersen's mermaid can obtain an immortal soul only by making a man fall in love with her, Ariel's ultimate objective is simply becoming Eric's wife. If Andersen's character can reach her goal only through a male mediator, Ariel rebels against the strict, patriarchal rules of her father King Triton only to live in the shadow of another male figure, Prince Eric.

The presence of men is felt less in the fairy tale, and yet it constitutes the counterpoint of femininity and female roles both under and above the surface of the sea in Walt Disney's The Little Mermaid. In Andersen's fairy tale, the Sea King is mentioned only a few times, to introduce the characters and to set the scene of the narration, but he does not have an active role in the Little Mermaid's choices or in her fate. Indeed, the Little Mermaid's mentor in life is her grandmother, the Sea King's mother. It is her grandmother who tells the Little Mermaid all she needs to know about humans and their souls; she is the sage, the one who holds and transmits knowledge and as such is a revolutionary figure for the time as, though she probably knows that free will and determination are not enough for a woman to reach personal achievement, she pushes her granddaughter to pursue her goal. The character of the grandmother is totally absent in Disney's adaptation and Ariel is instead surrounded by male characters who tell her what to do and how to do it: her authoritarian father, her helpers Sebastian the crab, Flounder the fish and Scuttle the seagull, and, last but not least, Prince Eric. The only other woman with whom she interacts (apart from the Sea-Witch) is the maid who arranges her bath at the royal palace, though on that occasion Ariel is already incapable of speaking and the maid's attitude towards her merely replicates that of the male characters: she treats Ariel as inexperienced and incapable. It could be argued, therefore, that if in Andersen's fairy tale women communicate with each other and across generations, in the Disney adaptation the idea of female solidarity and support is entirely absent. Neither is there any sense that solidarity and support between women can be a means for women's self-affirmation. In the Disney film, there 
Eleonora Federici, Emanuela Ammendola, Luisa Marino | Disney is a Gendered World | DOI: 10.12977/ocula2019-15

is not even any suggestion that Ariel has support from her family, her sisters appear only briefly in the concert scene to highlight Ariel's absence and then again later when she gets back to Atlantica and they are in the background putting on make-up. The only scene in which Ariel actually interacts with another woman is when she goes to the Sea-Witch's cave asking for two legs, and again with the Sea-Witch when Ariel fights with her in the final part of the movie to reach her happy ending. Thus, through the relationship between Ariel and Ursula, Disney managed not only to characterize once more the eternal fight between Good and Evil, but also to reinforce the stereotype of two women competing for one man. In Andersen's fairy tale, however, the Sea-Witch is a neutral character who has the power to help the Little Mermaid reach her goal but neither persuades nor dissuades her from obtaining what she wants. While the ending of Andersen's fairy tale is not a straightforwardly happy one as the Little Mermaid does not succeed in her mission to make the prince fall in love with her in three days, and so has to die and become a "daughter of the air", in Disney's version she marries her prince. Yet if Andersen pictured a woman who was able to choose for herself within the possibilities of the nineteenth century, Disney's mermaid obtains her happy ending because Prince Eric defeats Ursula; she is rescued by her prince. As Deborah Ross underlines, «yes, she gets her legs, she makes her stand, she marches - but only down the aisle, to marry some guy named Eric» (Ross 2004: 60). At no point in the movie does she seem capable of autonomy, her actions seem to be the result of merely a stubborn determination to marry the prince. The little mermaid becomes a princess and is remembered today across the globe as a princess. Her character has been chosen as one of the eight figures of the Disney Princesses World, a group of female Disney characters chosen for a merchandising campaign involving gadgets, videogames, clothes for little girls, and even movie sequels and prequels. If we look at the website dedicated to Disney Princesses, we read that Ariel is headstrong and determined to find true love, a characterization which clearly alludes to the patriarchal ideals expressed in the movie. This is the image young viewers take away from the film.

In correspondence with the female protagonist, the male central character is similarly traditional, the heir to a throne in search of a spouse. In Andersen's story the prince falls in love with a girl from a convent who he believes has rescued him, in the Disney movie the rescuer is an illusion, a figment of his imagination which then becomes reality when the Sea-Witch transforms herself and sings the same song he heard Ariel sing when she rescued him. Moreover, the love triangle of Andersen's story is recreated through the core element of the mermaid's voice which, together with her appearance, is the essence of her identity.

\section{Walt Disney's productions: how to adapt a literary source and make it a blockbuster}

Omissions, condensations, additions and amplifications (v. Newmark 1988; Chaume and Agost 2001; Pavesi 2005; Diaz Cintas 2008; Perego 2011) characterize the movie in comparison with the literary source. Firstly, the story 
Eleonora Federici, Emanuela Ammendola, Luisa Marino | Disney is a Gendered World | DOI: 10.12977/ocula2019-15

is not told by an extra-diegetic narrator but rather emerges from the dialogues between characters in relation to the supporting images which add further meaning to the story, e.g., the use of colours in the depiction of Ursula's frightening cave or the change in angle to show different perspectives in the central scenes of the story. The first scene opens with some mariners on a boat who sing the song Fathom Below, based on a story about a beautiful mermaid living in a hidden realm under the sea, a song which prepares the viewer (and the prince) for the discovery of Atlantica, Ariel's world whose name alludes to the mythical town. From the very beginning music is a core element of the narration, used either to introduce a plot development or, as with some examples we examine in greater depth later on, to enhance the communication of the characters' feelings and actions. The centrality of music is reiterated by the representation of the underworld in the second scene when King Triton (another mythical name) presents the court composer, the crab Sebastian, who is supposed to conduct the King's daughters in a concert in his honour. The music begins and Triton's daughters appear from shells and introduce themselves: Aquata, Andrina, Arista, Atina, Adella and Allana, all names beginning with the letter A. They are then supposed to introduce the seventh sister to the Court, Ariel (a name with a Shakespearean allusion) but they discover that the shell is empty, and Ariel is nowhere to be found, disobeying her father's will and disappointing the court. Her musical debut does not take place and the viewer is unable to hear the "voice like a bell" (LM). ${ }^{2}$ It is clear from the outset, then, that voice is a central element in the movie, understandable when we consider the fact that in children's movies song is key in conveying meanings and aiding the development of the narrative. The following scene then tells us where the little mermaid was during the concert scene, showing Ariel searching for human artefacts with her best friend Flounder, a timid little brightly coloured fish. In her wandering she finds a fork and a pipe, two common objects whose use is explained by the seagull Scuttle, who is intended to be the mediator between the underworld and the human world. The fork is given the name "dinglehooper" and the pipe "snarfblat" their uses are said to be "a sort of comb for babies' hair" and a musical instrument respectively (in the Italian version translated as "arriciaspiccia" which maintains the onomatopoeic sound and "soffiablabla" which conveys the idea of an instrument used in prehistoric times, as the seagull affirms). These neologisms have a humoristic effect on the young viewer, an emotional response that is supported by the visual element showing the seagull using the fork as a comb. It is at this point that Ariel remembers her father's concert and runs towards Triton, while her antagonist, Ursula, makes her first appearance, shown spying on the girl together with her servants Flotsam and Jetsam, two moray eels who are clearly intended to recall Andersen's portrayal of the marine snakes. Ursula longs for Triton's power, she wants to be the Queen of Atlantica. She is manipulative and cruel and both her body and personality are threatening; her characterization is immediately clear from her appearance (she is a large scary octopus creature with purple skin, heavy make-up and bright red lips), her words and the depiction of the place where she

2 All quotations (LM) are taken from the script. 
Eleonora Federici, Emanuela Ammendola, Luisa Marino | Disney is a Gendered World | DOI: 10.12977/ocula2019-15

lives (a dark frightening cave) as well as, once again, the music that accompanies her. She wants Ariel's soul because she wants to defeat Triton, not because she wants to marry Eric.

Ariel's longing for the human world is reiterated in the next scene where the Little Mermaid, together with Flounders, runs away from her father, who has scolded her because she has gone to the surface to look for human beings (whom he refers to as "barbarians", in the Italian version "selvaggi"). The musical element is here inserted with the famous song Part of Your World which deconstructs all the negative traits Triton attributes to humans in the previous dialogue. If Andersen's mermaid wanted to walk and climb, here Ariel wants to dance, stay all day in the sun and wander freely on land. The song explains these desires to the viewer, and then the following dialogue between Ariel and Sebastian - who is, however, a composer and not the tutor to a headstrong teenager - prepares the viewer for the scene that will follow where the first encounter between Ariel and Eric takes place (or rather where she sees him for the first time). While Ariel and Sebastian are having their conversation, a ship arrives, and the noise of fireworks is audible. Ariel moves towards it, first hears and then sees Eric. Here her eyes open wide and she murmurs "he is handsome» (LM) while listening to Grimsby (the Prince's tutor) as he babbles on about a possible wedding and the search for the perfect girl. The party is ended by a hurricane which causes the shipwreck. The rescue of the prince is also one of the core elements in Andersen's tale, but while in the literary text he believes that one of the girls from a nearby convent must have saved his life, in the movie it is the song Ariel sings which remains in his mind, like an obsessive thought. Ariel, represented through a visual intertextual reference to the famous mermaid statue in Copenhagen, sits on a rock watching him disappear into the distance and sings a short song about her desire to be with him and, once again, to be part of his world. The following day Sebastian tries to convince Ariel of the positive aspects of her own world and he does so through the memorable song Under the Sea. The girl however is not persuaded, and when she sees Eric's statue in her cave, she is even more determined to fulfil her personal desire to become human. The statue is an element adapted from the literary text and functions as symbol of the mermaid's characterization; it is an object of transfer between the two worlds. In the meanwhile, Triton, who has understood his daughter is in love, discovers the object of her affection and destroys the 'hidden treasure' (the term with which Ariel refers to her cave). This episode then leads to the pact between Ariel and the Sea-Witch. The viewer sees a simplified version of Andersen's description of the witch's cave, macabre references have been rendered visually softer, adapted to a child's gaze. Ursula reappears and even though the viewer knows she is the antagonist, her sense of humour and her rhetoric capabilities makes her a more sympathetic character than previously, at least for adult viewers. The potion Ursula gives Ariel will transform her into a human being for three days in exchange for her voice. Within those three days she needs to be kissed by the prince, a kiss of true love, and if this does not happen, she will become enslaved to the Sea-Witch, like the other unfortunate souls in her cave. The dialogue and song that follows is a further reinforcement of feminine stereotypes: 
Eleonora Federici, Emanuela Ammendola, Luisa Marino | Disney is a Gendered World | DOI: 10.12977/ocula2019-15

Ariel will renounce her family and her world but she will have her man, she will be mute but this is not important because she is pretty, and her look will function much better than her voice or thoughts to convince the prince she is the girl for him. After all, Ursula reassures her «men up there don't like a lot of blabber, they think a girl who gossips is a bore. Yes, on land it's much preferred for ladies not to say a word» (LM). Ariel signs the contract and she immediately gets her legs. The transformation is as easy and fast, all the pain present in the literary source is omitted, and the reference to the cutting of the tongue is adapted into a trapping of Ariel's voice in a shell. What remains of the literary text is an unambiguous reference to the importance of suffering for love and of renunciation and sacrifice for the loved one. When Ariel meets her prince, she is mute and he does not recognize in her the girl who rescued him as it was her voice which formed the basis of his memory. Following Sebastian's suggestion that she need to look her best - «bat her eyes» and «pucker up her lips» (LM) - Ariel follows Eric to the palace. The following day the couple visit the kingdom, as if the would-be princess were preparing herself for her future role, and while on the canoe all her friends try to make him kiss her in order to break the Sea-Witch's spell. Floating in the blue lagoon, they are accompanied by a song, as with all central passages in the movie. Having perceived this danger, Ursula transforms herself into a dark-haired girl possessing Ariel's voice and immediately casts a spell on the prince. The wedding is organized but luckily the Sea-Witch is unmasked by Scuttle who runs towards Ariel and her friends in order to save Eric. The wedding ship becomes the arena of a struggle between the witch against everyone else, until the shell releases Ariel's voice and Eric kills Ursula, who in the meanwhile has turned back into a dark octopus, thus losing her attractiveness. The happy ending reassures the public and changes the conclusion of the literary text entirely.

If we look closer at the dialogues, we realize that language is used to represent Ariel as the ideal woman for a prince. Her inability to speak is irrelevant to her attractiveness (and thus she is at her best when she remains mute) and the dialogues underline her beauty and behaviour rather than her personality traits (on land Ariel is not a rebel anymore). Both songs and dialogue convey the same gendered world common to all Disney movies, a world where women and men have very precise roles. The following example, taken from a scene when Ariel is at the palace clearly demonstrates how the protagonist is depicted as a sweet young girl who should be treated as such. Ariel enters the room where the prince and Grimsby are going to have dinner, she is accompanied by the maid Carlotta, who in the previous scene has also reiterated the girl's beauty and kindness:

\begin{tabular}{|l|l|}
\hline ST & TT \\
\hline Grimsby: Oh, Eric, isn’t she a vision? & Grimsby: Oh Eric, non è stupenda? \\
Eric: You look wonderful. & Eric: Sei bellissima. \\
\hline
\end{tabular}

Compliments communicate the men's admiration towards the girl as they talk between themselves without directly addressing her, even though she is in the same room. Grimsby refers indirectly to Ariel when addressing Eric, 
Eleonora Federici, Emanuela Ammendola, Luisa Marino | Disney is a Gendered World | DOI: 10.12977/ocula2019-15

the girl is depicted as a "vision". A term which relates to the previous idea of a non-existent girl while at the same time refers to a common metaphor for beauty (essere una visione would also work in Italian). The adjective "wonderful' is substituted with "bellissima" which seems to diminish the allusion to wonder about her appearance. The scene continues with Grimsby who invites Ariel to join them:

\begin{tabular}{|l|l|}
\hline ST & TT \\
\hline Grimsby: Come, come, come, you must & Grimsby: Avanti, vieni, vieni. Sarai \\
be famished. Let me help you my dear. & affamata. Lascia che ti aiuti, cara. Ecco... \\
There... oh... there we go. Ah! That's & aaaah.. ecco quà. Ah così va meglio. \\
better! Now, quite comfy? Uh, ah ah... & Allora, stai comoda eh? Eh eh eh. Non \\
It's... it's not often that we have such a & capita spesso di avere a cena un'ospite \\
lovely dinner guest, eh Eric? & così deliziosa, vero Eric? \\
\hline
\end{tabular}

The Italian text is rendered in less formal language (for example, the translation of the archaic term "famished" with "affamata") and avoids some of the repetitions of the ST. Grimsby's perception of Ariel is obvious in both versions with his pauses, sly grins and redundancies. Ariel's appearance is conveyed in the translation of terms referring to her, such as "lovely", into the Italian "deliziosa", which emphasizes her objectification even further. Ariel's behaviour in this unknown environment is comic, she uses the fork as a comb, and the pipe as a musical instrument, blowing ash into Grimsby's face. Paralinguistic elements here are important in the reception of the characters; their gestures, gazes and expressions. Indeed, as Ariel cannot talk, all her communication is non-verbal.

\begin{tabular}{|l|l|}
\hline ST & TT \\
\hline Grimsby: Uh, do you like it? It really is & Grimsby: ah ah, ti piace? Sai è un \\
rather fine... & oggetto piuttosto pregiato. \\
Carlotta: Oh, my! & Carlotta: oh ooo... oh cielo! \\
Eric: Ahem, so sorry Grim. & Eric: Ehm... mi dispiace Grim. \\
Carlotta: Why, Eric, that's the first & Carlotta: Dio ti benedica Eric! Erano \\
time I've seen you smile in weeks. & settimane che non ti vedevo sorridere! \\
\hline
\end{tabular}

The dialogue develops as if Ariel were an ignorant infant; she does not recognize even something as ordinary as a pipe. The translation of the dialogue justifies the characters' gestures, their expressions and their reactions. The insertion of the verb "to know" (sai) in the Italian puts greater emphasis on Grimsby's paternalistic attitude towards Ariel. The sentence becomes complete, with no presupposition of a continuation as is the case in the ST. Carlotta's exclamation which replaces the original phrase «Oh my!» is rendered as «oh cielo!» which expresses amazement. The following sentence in the TT -«Dio ti benedica Eric!», which means "God bless you Eric!" - refers to the «oh cielo» just pronounced and emphasizes once again the idea that the girl is a sort of blessing arrived from God to entertain the prince. 


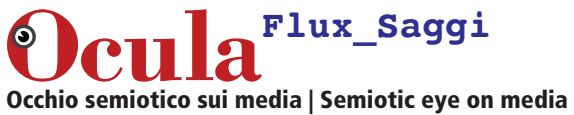

Eleonora Federici, Emanuela Ammendola, Luisa Marino | Disney is a Gendered World | DOI: 10.12977/ocula2019-15

\section{Singing the Italian Sirenetta}

The process of transposition to the screen represents a form of translation from one system of signs to another, where the concept of multimodality becomes prominent, given that a movie is primarly characterized by the cooperation of images and sounds. Multimodality (cfr. Gunther Kress 2010), which is central to audiovisual translation, has its most perfect example in music translation for children's movies where the challenge of the translator is to take into account not only the strict relationship between words and images, but also the co-occurrence of the music in the songs of the movie. The process of music translation is thus defined very effectively by the expression medium-constrained translation (cfr. Mayoral 1986), making clear the specific nature of this type of translation that has to deal with different channels and modes of communication at once (visual, acoustic, verbal and non-verbal). Songs are not always translated unless they play a specific role in the receiving system, as in animated movies where they do some of the work of revealing plot developments and so need to be comprehensible to the target audience - our example being one of those cases. Here, we focus on the musical texts of Disney's Little Mermaid that are part of the narrative content delivered by means of different semantic resources such as music, sound and speech (Theo van Leeuwen 1999). In addition to the difficulties of translation, writing for children also requires special considerations. Writing for an audience of children usually implies a level of simplification in the target language, that is to say the standardization and neutralization of elements in original dialogue or songs that are diaphasically or diastratically marked in the source language, or even of features belonging to the oral dimension such as hesitations or rewordings. This change may be due to the fact that cartoons have a pedagogical function in addition to an entertainment function, i.e. they have the aim of teaching children their mother tongue (cfr. De Rosa 2010: 7).

Turning now to the linguistics aspects of this branch of translation, the peculiar nature of music texts, characterized by a close relationship between form and content, is linked to the occurrence of the music, and the translator is being asked to make possible «the actual performance in the target language of foreign songs, with their pre-existing music» (Peter Low 2008: 2). Different strategies related to multiple linguistic and pragmatic issues- the communicative aim of the text, the function of the product, the nature of the target audience and the structural differences between source and target language- can be used in translating songs such as those listed by Johan Franzon (2008: 276):

- No translation.

- Translation of the text without considering the music.

- Creation of a new text that accords with the original music.

- Translation of the text modifying the music.

- Translation of the text adapting it to the music.

With regards to the relationship between music and lyrics Franzon introduces the concepts of prosodic match, poetic match and semantic-reflexive match. The prosodic match is obtained by the reproduction of the same prosodic ele- 
Eleonora Federici, Emanuela Ammendola, Luisa Marino | Disney is a Gendered World | DOI: 10.12977/ocula2019-15

ments (rhythm, stress, intonation) of the original melody. The poetic match concerns the harmonic structure of the song and is obtained when the rhyme scheme does not change in the target text, while the semantic-reflexive match is given by the words and their semantic value in the source- and target text (Franzon 2008: 389-396). If we compare the soundtracks of The Little Mermaid with La Sirenetta it is possible to recognize the original music and the patterns of the original melody, making the prosodic match possible. A partial preservation of the rhyme scheme shows, instead, some lacks in the poetic match, due to some stylisitc changes revealing the intention to be faithful in terms of lexical choices and semantic content.

Texts like Part of Your World and Poor Unfortunate Souls, sung by the main character Ariel and her antagonist Ursula respectively, concretely show these translation choices. In both texts, as in all songs in the movie, repetitions, assonances and inversions contribute to generally maintain the rhyming schemes, even though some of the 'poetic' elements are partially lost or changed in the process of translation from English to Italian in order to preserve the content. Among them we can identify modifications in terms of rhyme, many repetitions, as well as inversions of lines. It is not surprising to see, therefore, that the number of rhymes is usually higher in the source text than in the target text. This decrease is, however, compensated for by the use of repetitions and assonances in the translated version as shown by the song Part of your world in the following schema:

\begin{tabular}{|l|l|l|}
\hline & Part of your world & Parte del tuo mondo \\
\hline 1 & Look at this stuff & Guardate un po' \\
\hline 2 & Isn't it neat? & Quello che ho \\
\hline 3 & $\begin{array}{l}\text { Wouldn't you think my collection's } \\
\text { complete? }\end{array}$ & È una raccolta preziosa, lo so \\
\hline 4 & Wouldn't you think I'm the girl & Vi sembrerà che io sia \\
\hline 5 & The girl who has ev'rything? & Una che ha tutto ormai! \\
\hline 6 & Look at this trove & Che tesori! \\
\hline 7 & Treasures untold & Che ricchezze! \\
\hline 8 & $\begin{array}{l}\text { How many wonders can one cavern } \\
\text { hold? }\end{array}$ & Chi mai al mondo ne ha quanto me? \\
\hline 9 & Lookin' around here you'd think & Se guardi intorno dirai: \\
\hline 10 & Sure, she's got everything & Oh, che meraviglie \\
\hline 11 & I've got gadgets and gizmos aplenty & Ho le cose più strane e curiose \\
\hline 12 & I've got whozits and whatzits galore & Non ho nulla da desiderar \\
\hline 13 & $\begin{array}{l}\text { [You want thingamabobs? I got } \\
\text { twenty] }\end{array}$ & $\begin{array}{l}\text { [Vuoi un... come si chiama? Io ne ho } \\
\text { venti] }\end{array}$ \\
\hline 14 & But who cares & Ma lassù \\
\hline 15 & No big deal & Cosa mai \\
\hline 16 & I want more & Ci sarà \\
\hline 17 & I wanna be where the people are & Imparerei tutto già lo so \\
\hline
\end{tabular}


Dcula ${ }^{\text {Flux_Saggi }}$

Occhio semiotico sui media | Semiotic eye on media

Eleonora Federici, Emanuela Ammendola, Luisa Marino | Disney is a Gendered World | DOI: 10.12977/ocula2019-15

\begin{tabular}{|c|c|c|}
\hline 18 & I wanna see & Vorrei provare \\
\hline 19 & Wanna see 'em dancin' & Anche a ballare \\
\hline 20 & Walkin' around on those & E camminare su quei \\
\hline 21 & [Whad'ya call 'em? oh - feet] & [Come si chiamano? Ah piedi] \\
\hline 22 & Flippin' your fins you don't get too far & Con le mie pinne non si può far \\
\hline 23 & Legs are required & Vorrei le gambe \\
\hline 24 & For jumpin', dancin' & Per saltare \\
\hline 25 & Strollin' along down a & Ed andare a spasso per la \\
\hline 26 & [What's that word again?] street & [Come si dice? Strada] \\
\hline 27 & Up where they walk & Vedrei anch'io \\
\hline 28 & Up where they run & La gente che \\
\hline 29 & Up where they stay all day in the sun & $\mathrm{Al}$ sole sempre sta come vorrei \\
\hline 30 & Wanderin' free & Essere lì \\
\hline 31 & Wish I could be & Senza un perché \\
\hline 32 & Part of that world & In libertà \\
\hline 33 & What would I give & Come vorrei \\
\hline 34 & If I could live & Poter uscir \\
\hline 35 & Outta these waters & Fuori dall'acqua \\
\hline 36 & What would I pay & Che pagherei \\
\hline 37 & To spend a day & Per stare un po' \\
\hline 38 & Warm on the sand? & Sdraiata al sole \\
\hline 39 & Betcha on land & Scommetto che \\
\hline 40 & They understand & Sulla terra \\
\hline 41 & $\begin{array}{l}\text { Bet they don't reprimand their } \\
\text { daughters }\end{array}$ & Le figlie non le sgridano mai \\
\hline 42 & Bright young women & E nella vita \\
\hline 43 & Sick o’ swimmin’ & Poi fanno in fretta \\
\hline 44 & Ready to stand & Ad imparar \\
\hline 45 & $\begin{array}{l}\text { And ready to know what the people } \\
\text { know }\end{array}$ & Ti sanno incantare e conoscono \\
\hline 46 & Ask 'em my questions & Ogni risposta \\
\hline 47 & And get some answer & A cio che chiedi \\
\hline 48 & What's a fire and why does it & Che cosa è il fuoco e sai perché? \\
\hline 49 & [What's the word?] burn? & [Come si dice?] brucia? \\
\hline 50 & When's it my turn? & Ma un giorno anch’io \\
\hline 51 & Wouldn’t I love & Se mai potrò \\
\hline 52 & Love to explore that shore above? & Esplorerò la riva lassù \\
\hline 53 & Out of the sea & Fuori dal mar \\
\hline 54 & Wish I could be & Come vorrei \\
\hline 55 & Part of that world & Vivere là \\
\hline
\end{tabular}


Eleonora Federici, Emanuela Ammendola, Luisa Marino | Disney is a Gendered World | DOI: 10.12977/ocula2019-15

\begin{tabular}{|l|l|l|}
\hline & Part of your world II & Parte del tuo mondo II \\
\hline 56 & What would I give & Come vorrei \\
\hline 57 & To live where you are? & Stare qui con te \\
\hline 58 & What would I pay & Cosa darei \\
\hline 59 & To stay here beside you? & Per restarti accanto? \\
\hline 60 & What would I do to see you & Vorrei tu potessi \\
\hline 61 & Smiling at me? & Sorridermi \\
\hline 62 & Where would we walk? & Mi porterai \\
\hline 63 & Where would we run? & Dove vorrai \\
\hline 64 & If we could stay all day in the sun? & E del tuo mondo parte farò \\
\hline 65 & Just you and me & Accanto a te \\
\hline 66 & And I could be & Sempre così \\
\hline 67 & Part of your world & Solo con te \\
\hline 68 & I don't know when & Quando accadrà \\
\hline 69 & I don't know how & No non lo so \\
\hline 70 & But I know something's starting right & Ma del tuo mondo parte farò \\
\hline 71 & Watch and you'll see & Guarda e vedrai \\
\hline 72 & Some day I'll be & Che il sogno mio \\
\hline 73 & Part of your world & Si avvererà \\
\hline
\end{tabular}

Examples of assonances in the target text can be identified in lines 20 and 21 (quei/piedi) and 28 and 31 (che/perché) while an examples of repetition is the word vorrei, which occurs seven times in the song as well as the sentence del tuo mondo parte farò which occurs twice, in lines 64 and 70 . The latter sentence is also an example of a further peculiarity of music texts, namely the need to use syntactic structures which are not commonly used in prose. Indeed, unusual syntactic structures and ellipsis or apocope are not commonly used in Italian prose, but they are largely used in music texts where words and lines have to be arranged to the music. Examples of apocope can be found in lines 12 (desiderar), 34 (uscir) or 44 (imparar), while instances of unusual syntactic structures can be noted in lines 29 (al sole sempre sta come vorrei) or 64 (e del tuo mondo parte farò). This last example represents a mark of faithfulness to the original version, since, as title of the song, it is literally translated and taken up in the second part of the song even though it doesn't occur in the first. Another strategy used to preserve the original message is the inversion of some lines in the target text or the change of position of some information which is not lost, just located in different points in the TT. Inversions can be observed in the lines 46/47 ("ask them questions and get some answers") which has been swapped in the TT (ogni risposta a ciò che chiedi), 
Eleonora Federici, Emanuela Ammendola, Luisa Marino | Disney is a Gendered World | DOI: 10.12977/ocula2019-15

in addition to instances of a change of position such as line 30 of the ST ("wanderin' free") which is reported in the line 32 of the TT (in libertà).

At a lexical level some changes are required in the target text, but these changes are for the most part irrelevant. In the case of the song Les Poissons, however, there are significant changes. As with other songs from the movie, Les Poissons is characterized by a decrease in the number of rhymes in the target text, while there are several repetitions and instances of assonance. The lexicon of this song differs substantially from other songs due to the presence of a third language in both source and target text. French elements occur with the same frequency in both source and target text, but the English and the Italian versions differ due to differing perceptions of the French language in English and Italian audiences. While in the target text there are no explicitations linked to French items or phrases occurring in the song, the English version is characterized by the presence of elements that have the main aim of simplifying the comprehension of the French expressions. This phenomenon occurs in line 5 where the phrase "les poissons" is immediately followed by the English "little fish", or in line 30 where the French expression "quel dommage" is translated by means of the English phrase "what a loss". Moreover, French words are more frequent in the target text than in the source text, where words such as "delish" or "crab" are replaced by means of the French words joli and bijou.

Thus, the kind of translation that Franzon (2008: 276) identifies as the fifth type in his list, and which Low describes as "singability" in his "Pentathlon Principle", can be observed in the translation of songs from The Little Mermaid. Low considers music translation in terms of the cooperation of five criteria: singability, sense, naturalness, rhythm e rhyme (cfr. Low 2005: 185212). He states that «although song-texts usually have one rhyme per line, there is no law saying that a translation must replicate this» (Low 2008: 7). However, in the context of the cooperation between the song and the image on the screen, one last point should be introduced, which concerns the adaptation of the image to the target system. Broadly, it can be stated that form and content are on the same level in a music text. However, if the latter is translated with the purpose of transmitting the original message, the process of translation ought to take a position on the content rather than the form. It could be said, therefore, that all the songs of this animated movie share a common aim, which is to preserve the original content in the target text even at the expense of the form. Nonetheless, it should be pointed out that different strategies can be used in music translation to overcome the multiple linguistic and pragmatic issues presented, i.e., how to meet communicative requirements and adapt to the function of the product, type of audience and structural differences between source and target language.

To conclude, taking into account that music translation may require the adaptation of the original music by changing words and contents, which can in some cases lead to changes in the music or even a full change and a re-creation of the text, it can be said that in this specific case, just as in the majority of Disney movies, the process consists of a balanced adaptation of the original contents and music and therefore the changes made to the text style and con- 
Eleonora Federici, Emanuela Ammendola, Luisa Marino | Disney is a Gendered World | DOI: 10.12977/ocula2019-15

tent remain marginal. The objective has been to achieve the highest level of faithfulness possible.

It is clear that gender roles and representations pervade the movie in all its parts including its songs. The Little Mermaid is a movie clearly addressed to young girls and the main character is herself a young girl caught in a generational conflict with her father. References to her femininity occur in almost all songs, reinforcing the idea of a powerless young woman constrained by men's desires. The song Kiss the Girl reflects Ariel's submission to a man's will, and the fact she becomes mute renders her the ideal girl to marry in the song Poor Unfortunate Souls. Ariel's song Part of your World when rendered in Italian places even greater emphasis on her submissive position towards the prince; in lines 16, 17, 18, 19, 20 the repeated verb "wanna" is erased and transformed into more general terms "ci sarà", "imparerei", "vorrei provare", "vorrei". The use of the conditional underlines her wish to learn to be human, rendering the text in more formal language and adding the idea of her willingness to be part of the human world, something the audience is not sure will take place. In the second part of the songs all the references to herself and the prince "we" are translated with a focus on Eric "mi porterai dove vorrai, e del tuo mondo parte farò" "accanto a te" and "solo con te". The focus shifts from the couple to the male figure in isolation.

\section{Conclusions}

Animated movies are not straightforward texts; they reiterate gender roles and expectations. In the passage from the literary text to the Disney production of the Little Mermaid we can see how adaptation choices reveal not only selections and changes as regards both themes and character representations and actions, but also a desire to mould the story into something more traditional and conforming to accepted social and cultural norms. Dialogues and songs are created in order to offer a fairy tale that is reassuring because it is in-keeping with patriarchal norms, and the story is given a happy ending. If we analyse the dubbing of dialogues and songs in the Italian version, we can see how this adaptation to better suit conventional gender roles has been taken a step further with the use of language which further emphasizes the characterization of conventionally male and female characters. This cultural shift is visible from the title itself, the "little mermaid" is not simply "una piccola/giovane sirena" but rather a "sirenetta"; the use of a diminutive expresses both her young age (she is inexperienced and thus in need of guidance) and her beautiful physical appearance. The world created by Disney is highly gendered, making it easily relatable to most audiences and cultural contexts across the globe, given the planetary acceptance of gender roles and non-equal cultural productions. It will take a long time to critically revise cultural representations of femininities and masculinities, when it will happen we will sing a different song. 


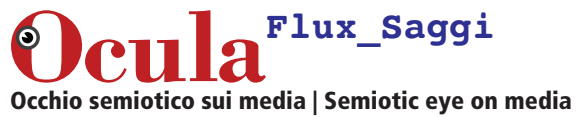

Eleonora Federici, Emanuela Ammendola, Luisa Marino | Disney is a Gendered World | DOI: 10.12977/ocula2019-15

\section{References}

Andersen, Hans Christian

1875 Hans Andersen's Fairy Tales, Translated by Mrs. Henry H. B. Paull, London, Warner \& Co.

1904 Quaranta novelle, Translated by Maria Pezzè Pascolato, Milano, Hoepli.

1938 Nuove novella, Translated by Mary Tibaldi Chiesa, Milano, Hoepli.

1949 The Complete Andersen, Translated by Jean Hersholt, New York, Heritage Press.

1954 Fiabe di Andersen, Translated by M. Rinaldi, A. Manghi, Torino, Einaudi.

1955 Nuovissime novelle, Translated by Mary Tibaldi Chiesa, Milano, Hoepli.

1993 Le fiabe, Translated by M.Pezzè Pascolato, G. Pozzo, K. Bech, Roma, Newton Compton.

1994 Fiabe, Translated by K. Bech, Roma, Newton Compton.

2001 Fiabe e Storie, Translated by Bruno Berni, Roma, Donzelli Editore.

2005 Fiabe e Storie, Translated by Bruno Berni, Roma, Donzelli Editore.

2012 Fiabe e Storie, Translated by Bruno Berni, Milano, Feltrinelli Editore.

2014 Fiabe e Storie, Translated by Bruno Berni, Roma, Donzelli Editore.

Applegate, Katherine

1993 King Triton, Beware! (Disney's the Little Mermaid), Glendale, Disney Press.

1993 The Haunted Palace (Disney's the Little Mermaid), Glendale, Disney Press.

1994 The Boyfriend Mix-Up (Disney's the Little Mermaid), Glendale, Disney Press.

Bacchilega, Cristina

1999 Postmodern Fairy Tales: Gender and Narrative Strategies, Philadelphia, University of Pennsylvania Press.

2013 Fairy Tales Transformed? Twenty-First-Century Adaptations and the Politics of Wonder, Detroit, Wayne State University Press.

Bluestone, George

1957 Novels into Film, Baltimore, Johns Hopkins University Press.

Carr, Jan

1993 Arista's New Boyfriend (Disney's The little mermaid), Glendale, Disney Press.

1993 Ariel the Spy (Disney's The Little Mermaid), Glendale, Disney Press.

Chaume, Frederic; Agost, Rosa (eds.)

2001 La traduccion en los medios audiovisuales, Universidad Jaume I, Castellon the la Plana.

Christopher, Jess

1994 Alana's Secret Friend (The Little Mermaid, No 12), Glendale, Disney Press.

Costanzo Cahir, Linda

2006 Literature into Film: Theory and Practical Approaches, Jefferson, McFarland.

Dahlerup, Pil et al.

1990 "Splash!: Six Views Of “The Little Mermaid”, Scandinavian Studies, 4, 1990, vol.62, $403-429$.

David, Peter et al.

1994 Disney's The Little Mermaid in The Hunt for the Redhead Down Under 4, Glendale, The Disney Publishing Group. 


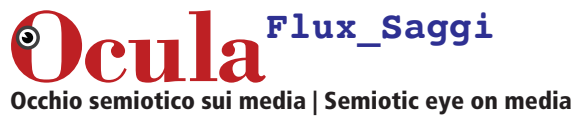

Eleonora Federici, Emanuela Ammendola, Luisa Marino | Disney is a Gendered World | DOI: 10.12977/ocula2019-15

De Rosa, Gian Luigi

2010 Dubbing Cartoonia, Napoli, Loffredo.

Desmidt, Isabelle

2009 “(Re)translation Revisited”, Meta, 4, 2009, vol.54, 669-683.

Diaz Cintas, Jorge

2008 The Didactics of Audiovisual Translation, Amsterdam, John Benjamins.

Donoghue, Emma

1997 Kissing the Witch: Old Tales in New Skins, New York, Harpercollins.

Dusi, Nicola

2006 Il cinema come traduzione. Da un medium all'altro: letteratura, cinema, pittura, Torino, UTET.

Eco, Umberto

2000 "Traduzione e interpretazione", Versus, 85/86/87, 2000, 55-100.

Franzon, Johan

2008 "Choices in Song Translation: Singability in print, Subtitles and Sung Performance", in Susam-Sarajeva, S. (ed.), Translation and Music (Translator), Abingdon-on-Thames, Routledge.

Gaiman, Neil

2014 The Sleeper and the Spindle, London, Bloomsbury.

Garcia, Alain

1990 L'adaptation du roman au film, Paris, Diffusion.

Genette, Gérard

1982 Palimpsestes. La littérature au second degré (Palimpsests: Literature in the Second Degree) Lincoln, University of Nebraska Press, 1997.

Giovagnoli, Max

2011 Transmedia Storytelling: Imagery, Shapes and Techniques, Milano, ETC Press.

Haase, Donald

1999 "Yours, Mine, or Ours? Perrault, the Brothers Grimm, and the Ownership of Fairy Tales", in Tatar, M (ed.), The Classic Fairy Tales, New York, Norton Critical Edition.

Hutcheon, Linda

2006 A Theory of Adaptation, New York, Routledge.

Jakobson, Roman

1959 "On Linguistic Aspects of Translation", in Brower, R. A. (ed), On Translation, Cambridge, Harvard University Press.

Kaindl, Klaus

2005 "The Plurisemiotics of Pop Songs Translation: Words, Music, Voice and Image", in Gorlée, D. L. (ed), Song and Significance: Virtues and Vices of Vocal Translation, Amsterdam \& New York, Rodopi.

Kaye, Marilyn

1992 Disney's The Little Mermaid: Reflection of Ursula, Glendale, Disney Press.

1992 Disney's The Little Mermaid: Same Old Songs, Glendale, Disney Press. 


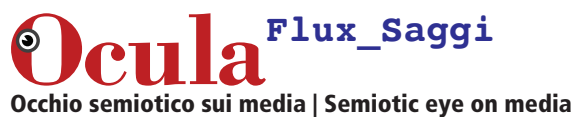

Eleonora Federici, Emanuela Ammendola, Luisa Marino | Disney is a Gendered World | DOI: 10.12977/ocula2019-15

Kress, Gunther

2010 "Multimodality: A Social Semiotic Approach to Contemporary", London: Routledge.

Low, Peter

2005 “The Pentathlon Approach to Translating Songs”, in Gorlée, D. L. (ed), Song and Significance: Virtues and Vices of Vocal Translation, Amsterdam \& New York, Rodopi.

2008 "Translating songs that rhyme", Perspectives: Studies in Translatology, 1-2, 2008, vol.16, $1-20$

Lluch Crespo, Gemma

2002 “Narración infantil y globalización”, CLIJ: Cuadernos de literatura infantil y juvenil, 152, 2002, 44-54.

Mayoral, Roberto; Dorothy, Kelly; Gallardo, Natividad

1986 "Concepto de traducción subordinada (cómic, cine, canción, publicidad). Perspectivas no lingüísticas de la traducción”, in AA. VV. Pasado, Presente y Futuro de la Lingüística Aplicada en España, Actas del III Congeso Nacional sobre Lingüistica Aplicada, Valencia, AESLA-Universidad de Valencia, 95-106.

McFarlane, Brian

2007 "It wasn't like that in the book" in Welsh, J. M.; Lev, P. (eds.) The Literature/ Film Reader: issues of adaptation, Lanham, Scarecrow Press.

Mortensen, Finn Hauberg

2008 "The Little Mermaid: Icon and Disneyfication", in Scandinavian Studies, 4, 2008, vol 80, 437-54.

Newmark, Peter

1988 A Textbook of Translation, New York, Prentice Hall.

O'Brien, Pamela Colby

1996 "The Happiest Films on Earth: A Textual and Contextual Analysis of Walt Disney's Cinderella and The Little Mermaid", Women's Studies in Communication, 2, 1996, vol.19, $155-183$.

Ozgenalp, Nur

2004 "Little Mermaids Swimming in the Patriarchal Seas", in Yoder, P; Kreuter, P. M. (eds.), Monsters and the Monstrous: Myths and Metaphors of Enduring Evil, Amsterdam, Rodopi.

Pavesi, Maria

2005 La traduzione filmica. Aspetti del parlato doppiato dall'inglese allitaliano, Roma, Carocci.

Perego, Elisa

2011 La traduzione audiovisiva, Roma, Carocci.

Rajewsky, Irina O.

2005 "Intermediality, Intertextuality and Remediation: A Literary Perspective on Intermediality”, Intermédialités, 6, 2005, 43-64.

Robbins, Trina et al.

1995 Disney's The Little Mermaid: Of Myths and Mermaids 12, New York, Marvel Comics. 


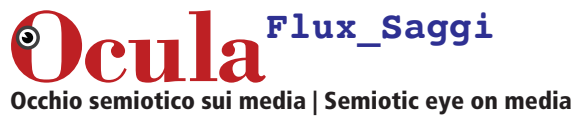

Eleonora Federici, Emanuela Ammendola, Luisa Marino | Disney is a Gendered World | DOI: 10.12977/ocula2019-15

Rodiguez, K.S.

1994 The Dolphins of Coral Cove (The Little Mermaid, No 11), Glendale, Disney Press.

Ross, Deborah

2004 "Escape from Wonderland: Disney and the Female Imagination", Marvels \& Tales, 1, 2004, vol.18, 53 - 66. Sanders, Julie

2006 Adaptation and Appropriation, London, Routledge.

St. Pierre, Stephanie

1994 The Practical Joke War (Disney's the Little Mermaid Novels, No 9), Glendale, Disney Press.Teverson, Andrew

2013 Fairy Tale, Abingdon-on-Thames, Routledge.Trites, Roberta

1991 "Disney's Sub/Version Of Andersen's The Little Mermaid", Journal of Popular Film and Television, 4, 1991, vol.18, 145-152.

Vanoyen, Francis

1998 La sceneggiatura, forme, dispositivi, modelli, Torino, Lindau.

Venuti, Lawrence

2007 "Adaptation, Translation, Critique", Journal of Visual Culture, 6, 2007, 25-43.

2012 Translation Changes Everything: Theory and Practice, London, Routledge.

Waller, Hastings Albert

1993 "Moral Simplification in Disney's The Little Mermaid", The Lion and the Unicorn, 1, 1993, vol.17, 83-92.

Weyn, Suzanne

1992 Green-Eyed Pearl (Disney’s the Little Mermaid Series), Glendale, Disney Press.

Weyn, Suzanne

1992 Nefazia Visits the Palace (Disney's the Little Mermaid Series), Glendale, Disney Press.

Zipes, Jack

1999 "Breaking the Disney Spell", in in Tatar, M (ed.), The Classic Fairy Tales, New York, Norton Critical Edition

2006 Why Fairy Tales Stick: The Evolution and Relevance of a Genre, Abingdon-on-Thames, Taylor \& Francis.

Eleonora Federici holds a PhD in English from the University of Hull and is Associate Professor of English Linguistics at the University of Naples L'Orientale. She has extensively published in the field of Translation Studies, the language of advertising, the language of tourism and English varieties. Her main publications include Translating Gender (2011), Bridging the Gap between Theory and Practice in Translation and Gender Studies (co-edited with V. Leonardi 2013), Quando la fantascienza è donna. Dalle utopie femminili del secolo XIX all'età contemporanea (2015), and the recent monographic issue of VIA Voices in Italia Americana "Italian Diaspora Studies" (co-edited with F. Gardaphè 2016).

Emanuela Ammendola is PHD student at the University of Naples Parthenope. Fields of interest of her research are Translaton Studies, LSP and AVT. She studied linguistic and cultural mediation at the University of Naples l'Orientale with a bache- 


\section{Ocula ${ }^{\text {Flux_saggi }}$ \\ Occhio semiotico sui media | Semiotic eye on media}

Eleonora Federici, Emanuela Ammendola, Luisa Marino | Disney is a Gendered World | DOI: 10.12977/ocula2019-15

lor's degree dissertation titled La memoria nella lingua. Lo Yiddish nel gergo di Berlino (a.a. 2013/2014). Shifting attention towards English she got her master's degree in LSP at the University of Naples l'Orientale with a dissertation on the audiovisual translation from English into Italian of children's movies titled La multimodalità della traduzione audiovisiva. The Little Mermaid: adattamento linguistico e culturale (a.a. 2016/2017).

Luisa Marino is a Ph.D Student in English and Translation Studies at the University of Naples “L'Orientale”. She earned a Master's Degree in Comparative Literatures and Cultures from the University of Naples L'Orientale, with a dissertation entitled Scrittura e Traduzione come pratiche liminari. La traduzione di "Days and Nights in Calcutta" di Clark Blaise e Bharati Mukherjee. She is currently researching in the field of Nigerian contemporary literature, dealing specifically with female writers and the linguistic representations of feminine bodies in translation. Her interests range from Translation Studies to Gender Studies and Post-colonial Studies. She is a literary translator from English and Portuguese. 